P-ISSN: 2615-1723

E-ISSN: 2615-1766

Oktober 2019
Jurnal Riset Pendidikan Dasar 02 (2), (2019) 81-88

Submitted: Juli, Accepted Agustus, Published: Oktober

\title{
Implementasi Penguatan Pendidikan Karakter di Sekolah Dasar Qur'ani Al-Ikhlash Rappang Kabupaten Sidenreng Rappang
}

\author{
Jumiati $^{1^{*}} \&$ Lababa $^{2}$ \\ ${ }^{1}$ Program Studi Pendidikan Bahasa dan Sastra Indonesia \\ ${ }^{2}$ Program Studi Pendidikan Bahasa Inggris \\ ${ }^{1,2}$ Fakultas Keguruan dan Ilmu Pendidikan Universitas Muhammadiyah Sidenreng Rappang, Indonesia \\ *Korespondensi.E-mail: jumiati@umsrappang.ac.id
}

\begin{abstract}
Abstrak
Penelitian ini dilakukan dengan tujuan untuk mendeskripsikan: 1) bagaimana profil Sekolah Dasar Qur'ani Al-Ikhlash Rappang Kabupaten Sidenreng Rappang; dan 2) implementasi penguatan pendidikan karakter di Sekolah Dasar Qur'ani Al-Ikhlash Rappang Kabupaten Sidenreng Rappang. Penelitian ini merupakan penelitian deskriptif dengan menggunakan data kualitatif serta pendekatan studi kasus. Sumber data dalam penelitian terdiri atas kepala sekolah, pengajar, orang tua siswa, dan siswa. Sekolah Dasar Qur'ani Al-Ikhlash Rappang. Teknik pengumpulan data dilakukan dengan teknik observasi, wawancara dan dokumentasi. Data yang dihasilkan dianalisis menggunakan teknik Milles \& Huberman yang meliputi: reduksi data, penyajian data dan verifikasi data. Untuk menguji keabsahan data, peneliti menggunakan triangulasi sumber dan triangulasi metode. Hasil penelitian menunjukkan bahwa: 1) Sekolah Dasar Qur'ani Al Ikhlash Rappang adalah salah satu lembaga pendidikan dasar berbasis Islam yang berlokasi di Rappang, Kecamatan Pancarijang, Kabupaten Sidrap, Sulawesi Selatan, Indonesia. Sekolah ini didirikan pada tahun 2014 atas kerjasama antara Yayasan Wahdaisamiyah Kabupaten Sidenreng Rappang dengan masyarakat serta orang tua siswa. Sekolah ini beroperasi dengan sistem fullday school dan memiliki visi "bertauhid dan berprestasi"; 2) implementasi penguatan pendidikan karakter sekolah dasar Qur'ani Al Ikhlash Rappang dilakukan melalui budaya dan sistem sekolah yang meliputi: keteladanan, tarbiyah, pengkondisian, nasihat baik yang repetitif, pola komunikasi, dan konsep 9K (kerapian, kebersihan, ketertiban, kesopanan, keindahan, kerindangan, kedisiplinan, keimanan, dan ketakwaan). Implementasi pendidikan karakter mandiri dilakukan dengan membersihkan lingkungan sekolah dengan kesadaran sendiri. Setiap hari, guru memberikan keteladanan menjaga kebersihan lingkungan sekolah, sehingga siswa memiliki kebiasaan membersihkan kelas masing-masing tanpa diperintah.
\end{abstract}

Kata Kunci: Pendidikan Karakter; Penguatan; Sekolah Dasar Qur'ani Al Ikhlash

\section{The Implementation of Reinforcement Education Character at Elementary School Qur'ani Al- Ikhlash Rappang Sidenreng Rappang Regency}

\begin{abstract}
This research aim to description: 1) how profile elementary school Qur'ani Al-Ikhlas Rappang (Sidenreg Rappang Regency), and 2) reinforcement of Implementation education character at elementary school Qur'ani Al- Ikhlas Rappang (Sidenreng Rappang Regency). This research it was descriptive kualitative research through case study. The
\end{abstract}

Copyright C2019, JRPD, ISSN 2615 - 1723 (Print), ISSN 2615 - 1766 (Online) 
data resources were; head master, teachers, Parents, and pupil of elemntary school Qur'ani Al-Ikhlas Rappang. Technique collecting data by using observation, intervew and documentation. Data analysis by using Milles \& Huberman technique was covered; data reduction, provided data, verification data. To make validitatioan data, the research was used triangulasi sources and triangulasi method. The research result showed that was; 1) elementary school Qur'ani Al- Ikhlash Rappang was one of the basic Islamic private elemntary school, located in Rappang, Distric pancarijang, Sidenreng Rappang regency, south sulawasi, Indonesia. This school was builded in 2014 as collabaration Wahdaislamiyah Sidenreng Rappang Regency with inhabitants, and parents of the students. This institute was overation by fullday school system and have point of view " bertauhid dan berprestasi"; 2) Implementation education character elemntary school Qur'ani Al-Ikhlash Rappang implemnted through culture and school system as well as; best attitude, education, makes good condition, good suggest, good communication, $9 K$ concep (kerapian, kebersihan, ketertiban, kesopanan, keindahan, kerindangan, kedisiplinan, keimanan, dan ketaqwaan). The aplication of education charakter through cleaning around school with self awarness. Everyday, teachers showed attitude to keep clean around the school, as well as students have become accustomed to cleaned their class without command.

Keywords: Education Character; Reinforcement; Elementary School Qur'ani Al Ikhlash

\section{PENDAHULUAN}

Sekolah Dasar merupakan basis pengembangan karakter pada jenjang pendidikan formal. Oleh karena itu, sangat diperlukan model pendidikan karakter yang efektif (Zuchdi, 2010). Sebagai upaya penanaman moral dan nilai-nilai kebangsaan di sekolah-sekolah dasar, pemerintah mewujudkannya melalui Program Penguatan Pendidikan Karakter (PPK) yang kemudian diterjemahkan ke dalam kurikulum nasional. Penguatan Pendidikan Karakter (PPK) ini juga merupakan salah satu butir Nawa Cita yang digagas oleh Presiden Joko Widodo yakni penyelenggaraan revolusi karakter (Saptiana, 2017). Nawa Cita yang digagas oleh presiden bukan tanpa alasan, Indonesia saat ini dapat dikatakan krisis karakter. "Kebobrokan mental dan karaktek di kalangan remaja, khususnya peserta didik merupakan permasalahan yang sulit diuraikan, bagaikan benang kusut yang sulit diuraikan pangkal dan ujungnya" (Handayani, 2017).

Pendidikan karakter tidak cukup hanya diajarkan di rumah dan lingkungan masyarakat namun juga harus dibekalkan dari sekolah. Pemahaman kepala sekolah dan guru terhadap program pendidikan karakter yang baik akan mendukung jalannya penguatan pada nilai karakter di sekolah tersebut dibanding jika pihak sekolah tidak memahami (LB, Danim, \& Somantri, 2018). Menambah porsi pendidikan yang bernuangsa karakter positif di sekolah dapat mengakselerasi peningkatan karakter bangsa. Oleh karena itu, masyarakat Indonesia patut menyambut baik peraturan pemerintah untuk mengenalkan Program Pengutan pendidikan karakter (PPK) di seluruh jenjang pendidikan.

Iskandar (LB, Danim, \& Somantri, 2018) menyatakan bahwa faktor yang mendukung pelaksanaan program pendidikan karakter adalah adanya kerja sama yang baik, lingkungan yang kondusif, fasilitas sekolah yang memadai, dan adanya perhatian dan komunikasi yang baik antara pihak sekolah dengan orang tua/wali siswa. Faktor penghambat dalam proses penguatan nilai karakter bagi siswa adalah adanya siswa yang kurang termotivasi oleh keluarga atau lingkungan rumah/keluarga yang kurang mendukung program sekolah. Pada hakikatnya, karakter yang baik harus dilaksanakan dengan cara pembiasaan yang baik pula (Suci \& Hidayat, 2019).

Pendidikan adalah sebuah penanaman modal manusia untuk masa depan dengan membekali generasi muda dengan budi pekerti yang luhur dan kecakapan yang tinggi. Pada umumnya dalam mencetak tumbuh kembang dan karakter anakterdapat di tiga lingkungan yakni pendidikam keluarga (pendidikan informal), sekolah (pendidikan formal), dan masyarakat (pendidikan non formal).Jadi baik buruknya akhlak/karakter seseorang dan tinggi rendahnya kecakapan atu keahlian seseorang dipengaruhi oleh tiga lingkungan pendidikan tersebut, yang mana ketiga lingkungan tersebut terkenal dengan istilah tri pusat pendidikan Copyright $\odot 2019$, JRPD, ISSN 2615 - 1723 (Print), ISSN 2615 - 1766 (Online) 
(Nurhadi, 2018). Gagalnya pendidikan pada tahap dasar terutama dalam pembinaan sikap/nilai diyakiniakan berdampak sistemik terhadap pendidikan berikutnya (Sari, Nasution, \& Wijaya, 2019). Oleh Sebab itu, pendidikan karakter menjadi penting untuk diselenggarakan di sekolah karena mengemban tiga fungsi penting sebagai berikut.

Namun, era digital saat ini memberi tantangan baru bagi pelaksanaan program pendidikan karakter di sekolah dasar. Anak pada usia dasar tidak telah mengenal gaya hidup digital, baik di rumah, teman-temannya, sekolah dan lingkungan sekitarnya. Era digital tidak hanya menawarkan manfaat positif namun juga memiliki dampak negatif (Putri \& Palupi, 2018). Oleh karena itu, dalam implementasinya dibutuhkan peran orang tua, pendidikan, dan masyarakat.

Sementara dalam penelitiannya, Iskandar (LB, Danim, \& Somantri, 2018) menyatakan bahwa faktor yang mendukung pelaksanaan program pendidikan karakter adalah adanya kerja sama yang baik, lingkungan yang kondusif, sarana dan prasarana yang memadai, dan adanya perhatian dan komunikasi yang baik antara pihak sekolah dengan orang tua/wali siswa. Faktor penghambat dalam pelaksanaan pendidikan karakter adalah adanya siswa yang kurang termotivasi oleh keluarga atau lingkungan rumah/keluarga yang kurang mendukung program sekolah. Pada hakikatnya, karakter yang baik harus dilaksanakan dengan cara pembiasaan yang baik pula (Suci \& Hidayat, 2019).

Dalam kajian lain, Pambudi (Pambudi \& Riyan, 2017) menunjukkan bahwa kegiatan implementasi penguatan pendidikan karakter kreatif dapat dilakukan dengan menggunakan cara kegiatan rutin, keteladanan, pengkondisian, sosialiasi, dan kerjasama. Menurutnya, Implementasi penguatan pendidikan karakter kreatif dilaksakan setiap hari minggu melalui kegiatan bersama membuat kerajinan dengan memanfaatkan berbagai bahan di sekitar sekolah. Pengajar di Sekolah Kreatif si Doel juga memberikan contoh karakter kreatif melalui kegiatan kerajinan. Selain itu, dinding-dinding tembok sekolah ini dicat semenarik mungkin. Berdasarkan temuan tersebut peneliti menyimpulkan bahwa Sekolah Kreatif Si Doel memiliki kreatifitas yang tinggi. Senada dengan hal tersebut, Mardian dalam penelitiannya juga menyimpulkan bahwa pendidikan karakter bisa diajarkan melalui permainan edukatif, misalnya menggambar dan bercerita (Mardian \& Muliyani, 2018).

Secara khusus, dalam pendidikan karakter di madrasah, semua komponen (pemangku pendidikan) harus dilibatkan, termasuk komponen-komponen pendidikan itu sendiri, yaitu isi kurikulum, proses pembelajaran dan penilaian, penanganan atau pengelolaan mata pelajaran, pengelolaan madrasah, pelaksanaan aktivitas atau kegiatan ko-kurikuler, pemberdayaan sarana prasarana, pembiayaan, dan ethos kerja seluruh warga madrasah (Ma'arif \& Hamid, 2018).

Mencermati latar belakang tersebut, maka tujuan yang ingin dicapai dari pelaksanaan penelitian ini adalah mendeskripsikan: Profil Sekolah Dasar Qur'ani Al Ikhlash Rappang Kabupaten Sidenreng Rappang; Implementasi penguatan pendidikan karakter di Sekolah Dasar Qur'ani Al Ikhlash Rappang Kabupaten Sidenreng Rappang.

\section{METODE}

Penelitian ini dilaksanakan di Sekolah Dasar Qur'ani Al-Ikhlas Rappang Kabupaten Sidenreng Rappang. Pemilihan sekolah ini sebagai tempat penelitian dilakukan melalui pertimbangan adanya informasi dari masyakarat mengenai perkembangan karakter siswa yang cukup signifikan di sekolah ini. Oleh sebab itu, penulis ingin menelaah implemetasi penguatan pendidikan karakter yang diimplemantasikan di sekolah tersebut.

Penelitian ini terdiri atas variabel tunggal yakni implementasi penguatan pendidikan karakter di Sekolah Dasar Qur'ani Al-Ikhlas Rappang Kabupaten Sidenreng Rappang.

Penelitian ini merupakan penelitian deskriptif dengan menggunakan data kualitatif

Copyright $\odot 2019$, JRPD, ISSN 2615 - 1723 (Print), ISSN 2615 - 1766 (Online) 


\section{Jurnal Riset Pendidikan Dasar, 02 (2), Oktober 2019 (81-88)}

Jumiati \& Lababa

serta pendekatan studi kasus. Untuk menguji keabsahan data digunakan teknik triangulasi sumber.

Sumber data dalam penelitian terdiri atas kepala sekolah, pengajar, orang tua siswa, dan siswa Sekolah Dasar Qur'ani Al-Ikhlas Rappang.

Teknik pengumpulan data dilakukan dengan teknik observasi, wawancara dan dokumentasi.

Data yang dihasilkan akan dianalisis menggunakan teknik Milles \& Huberman yang meliputi: reduksi data, penyajian data dan verifikasi data. Reduksi data merupakan langkah awal untuk merangkum, memilih, dan memfokuskan telaah pada hal-hal pokok terkait variabel penelitian. Hasil penelitian disajikan dalam bentuk deksripsi secara jelas dan rinci. Sementara, verifikasi data atau penarikan kesimpulan merupakan langkah akhir untuk mencocokkan data dengan teknik triangulasi sumber dan metode.

\section{HASIL DAN PEMBAHASAN}

Tujuan yang ingin dicapai dalam penelitian ini yakni untuk mengetahui bagaimana profil Sekolah Dasar Qur'ani Al Ikhlash Rappang dan bagaimana implementasi penguatan pendidikan karakter di Sekolah Dasar Qur'ani Al Ikhlash Rappang. Hasil Penelitian menunjukkan:

\section{Sekolah Dasar Qur'ani Al Ikhlash Rappang}

Sekolah Dasar (SD) Qur'ani Al Ikhlash Rappang adalah salah satu lembaga pendidikan dasar berbasis Islam yang berlokasi di Rappang, Kecamatan Pancarijang, Kabupaten Sidenreng Rappang, Sulawesi Selatan, Indonesia. Sekolah ini didirikan pada tahun 2004 atas inisiasi dan kolaborasi antara Yayasan Wahdaisamiyah Kabupaten Sidenreng Rappang dengan masyarakat setempat serta orang tua siswa. Berada di bawah binaan Yayasan Wahdaislamiyah yang konsen pada pendidikan Islami, sekolah ini bukanlah sekolah pertama yang dibangun oleh Yayasan. Sebelumnya, Yayasan Wahdaislamiyah telah lebih dahulu membangun dan membina lembaga pendidikan tingkat Taman Kanak-kanak (TK) yang diberi nama TK Qur'ani Al Ikhlash Rappang. Taman Kanak-kanak ini dibangun pada tahun 2013 dengan dana pembangunan ditopang oleh sejumlah donatur dari warga Wahdaislamiyah Kabupaten Sidenreng Rappang.

Setelah berjalan selama setahun, tepatnya pada tahun 2014 , lulusan pertama TK Qur'ani Ikhlash Rappang yang berjumlah 13 orang siswa akhirnya tamat. Namun, orang tua siswa kebingungan mencari sekolah dasar bagi anak-anak mereka untuk melanjutkan pendidikan. Orang tua siswalah yang pertama kali mencetuskan ide untuk membangun sekolah dasar, dengan pertimbangan bahwa mereka berharap konsep sekolah yang selama ini di terapkan di TK Qur'ani mampu memberi perubahan besar bagi anak-anak mereka. Salah satu orang tua siswa, $\mathrm{Hj}$. Nurhayati (42 tahun) berpendapat bahwa di zaman ini sekolah yang memfokuskan pendidikan pada akhlak dan cinta Qur'an itu sangat penting. Inisiatif mendirikan Sekolah tingkat dasar tersebut kemudian disampaikan kepada pengelola yayasan Wahdaislamiyah. Hingga pada akhirnya gedung SD Qur'ani resmi dibuka pada tahun 2014, selanjutnya menerima surat izin operasional dari pemerintah pada tahun 2015.

Pada tahun pertama, SD Qur'ani Al Ikhlash Rappang hanya mampu melakukan sosialisasi secara internal. Sehingga siswa yang terdaftar hanya berasal dari lulusan TK Qur'ani Al Ikhlash Rappang itu sendiri, yakni tiga belas (13) orang siswa dengan empat orang guru saat itu. Dua tahun kemudian tepatnya 2016, SD Qur'ani Al Ikhlash mulai melakukan sosialisasi secara terbuka ke khalayak melalui pamflet, brosur dan informasi di media sosial. Pada saat yang sama, penerimaan tenaga pengajar dibuka secara resmi. Pada akhirnya, menjelang tahun ketiga beroperasi, Sekolah Dasar Qur'ani Al Ikhlash Rappang telah memiliki sejumlah 69 orang siswa yang tersebar di tiga kelas. Sementara guru atau tenaga pengajar berjumlah 11 orang.

Upaya yang dilakukan Yayasan Wahdaislamiyah dalam mendirikan SD Qur'ani Al Ikhlash Rappang dilandasi atas pandangan bahwa mendirikan sekolah merupakan bentuk ibadah kepada Allah Swt. serta amanah kepada bangsa dan negara.

Copyright (O2019, JRPD, ISSN 2615 - 1723 (Print), ISSN 2615 - 1766 (Online) 
Dalam mengelola lembaga, SD Qur'ani Al Ikhlash Rappang berpegang pada visi, yakni "Bertauhid dan Berprestasi". Visi yang jelas dan visioner tentu memiliki landasan yang kuat pula. Beberapa rujukan yang melandasi pencetusan visi tersebut dapat ditemukan dalam Al Qur'an dan Al Hadist, di antaranya: 1. Al Qur'an Surah Lukman

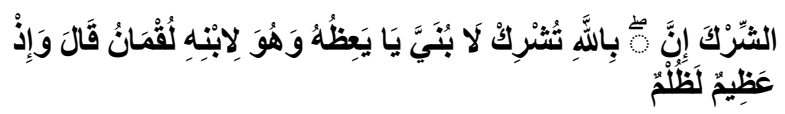

Artinya: "dan (ingatlah) ketika Lukman berkata kepada anaknya, ketika dia memberi pelajaran kepada anaknya. "Wahai anakku! janganlah engkau mempersekutukan Allah. Sesungguhnya mempersekutukan (Allah) adalah benar-benar kezaliman yang besar." (QS Lukman 31:13)

2. Al Quran Surah Al-Qalam

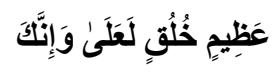

Artinya: "dan sesungguhnya kamu benarbenar berbudi pekeri yang agung" (QS. AlQalam 68:4)

3. Hadits Rasululah saw.

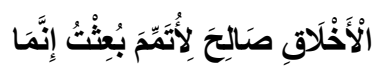

Artinya " sesungguhnya aku diutus, (tiada lain, kecuali) untuk menyempurnakan akhlak yang mulia." (HR. Ahmad 2:381)

Dalam rangka mencapai visi "Bertauhid dan Berprestasi", SD Qur'ani Al Ikhlash Rappang merumuskan misi, yakni:

a. Mengamalkan Al Qur'an dan As Sunnah sesuai dengan pemahaman salafussholih.

b. Mengembangkan pembelajaran berbasis keislaman dan prestatif.

c. Mengembangkan 9K (kerapian, kebersihan, ketertiban, kesopanan, keindahan, kerindangan, kedisiplinan, keimanan, dan ketakwaan).

Visi misi tersebut dirumuskan dan dilaksanakan dengan penuh kedisiplinan dan tanggung jawab untuk mencapai tujuan SD Qur'ani Al Ikhlash Rappang, yakni.

1. Sekolah mampu menghasilkan peserta didik yang mengamalkan Al Quran an As
Sunnah, taat beribadah, berakhlak mulia, dan gemar bersedekah.

2. Sekolah mampu mengembangkan kurikulum nasional yang terintegrasi dengan nilai keislaman.

3. Sekolah mewujudkan manajemen SDM, pengelolan, dan pembiayaan sekolah yang efektif dan amanah.

4. Sekolah menyelenggarakan pembelaaran yang mudah dan menyenangkan yang berdampak pada karakter peserta didik.

5. Sekolah menyelenggarakan penilaian otentik berbasis kelas secara efekif.

Sebagai sekolah yang berbasis Islam dengan sistem fullday school, SD Qur'ani Al Ikhlash kini menjadi salah satu ikon pendidikan dasar di Kabupaten Sidenreng Rappang, khususnya di Kecamatan Pancarijang dan beberapa wilayah di sekitarnya. Sejak beroprasi hingga saat ini jumlah siswa terus bertambah. Pada tahun keenam ini, kelas tertinggi adalah kelas enam (6), dengan jumlah siswa 32 orang.

\section{Implementasi Penguatan Pendidikan Karakter} Berdasarkan temuan di lapangan melalui kegiatan observasi, wawancara ditemukan bahwa implementasi penguatan pendidikan karakter sekolah dasar Qur'ani Al Ikhlash Rappang dilakukan melalui budaya dan sistem sekolah yang meliputi: keteladanan, tarbiyah, pengkondisian, nasihat baik yang repetitif, pola komunikasi, dan konsep 9K (kerapian, kebersihan, ketertiban, kesopanan, keindahan, kerindangan, kedisiplinan, keimanan, dan ketakwaan). Temuan-temuan tesebut dideskripsikan sebagai berikut.

\section{Karakter Religius}

Karakter religius yang melekat pada diri siswa SD Qur'ani Al Ikhlash Rappang nampak pada kegiatan sehari-hari, di antaranya: 1) kebiasaan membaca al Qur'an sebelum memulai pembelajaran; 2) pada saat jajan, siswa senangtiasa mengikuti cara makan yang disunnahkan oleh Rasulullah Saw yaitu menyentuh dan menyuap makanan dengan menggunakan tangan sebelah kanan serta makan dengan posisi badan tidak sedang berdiri. Bahkan sejumlah siswa kerap saling menegur jika salah satu temannya melupakan sunnah nabi tersebut; 3) pada saat jam istirahat, terekam seorang siswa bernama Copyright $@ 2019$, JRPD, ISSN 2615 - 1723 (Print), ISSN 2615 - 1766 (Online) 
Kamila (kelas 1) mengambil uang kertas di saku bajunya lalu memberikan kepada nenek pemulung. Saat ditanya alasan Kamila memberikan uang kepada nenek itu, jawaban Kamila sangat mengejutkan "kasian nenek itu, nenek itu sudah lama jadi pemulung di sini, tidak ada keluaranya. Kata ustazah kita harus bersedekah kepada orang yang tidak mampu"; 4) kegiatan salat dhuha dan salat zuhur secara berjamaah. Salat berjamaah dilakukan di masjid sekolah, yang bertindak sebagai imam salat adalah sisa kelas 5 dan kelas 6 yang telah memiliki makhroj al Qur;an yang baik.

\section{Karakter Nasionalisme}

Di lingkungan sekolah, dapat dilihat bahwa karakter nasionalisme siswa terwujud dalam kegiatan upacara dan kegiatan proses belajar mengajar. Misal, siswa kelas satu menghafal butir-butir Pancasila dengan semangat lengkap dengan simbolnya. Satu persatu akan diberikan kesempatan untuk tampil di depan kelas menceritkan salah satu simbol Pancasila yang mereka sukai lengkap dengan butirnya.

\section{Karakter Mandiri}

Salah satu kegiatan rutin yang selalu ditunggu-tunggu oleh siswa di sekolah adalah jam istirahat. Pada waktu itu, siswa boleh meninggalkan kelas bahkan boleh berbaur dengan teman-temannya di lapangan. Siswa perempuan boleh turun ke lantai satu, di mana ruangan kelas laki-laki berada, mereka boleh saling menyapa dan jajan bersama. Selain kantin, sekolah juga menyediakan makan siang kepada siswa yang dikemas dalam kotak makanan yang berwarna-warni. Setelah makan siang, siswa memberekan dan merapikan kotak makanannya masing-masing di tempat yang tersedia.

\section{Karakter Gotong Royong}

Kegiatan gotong-royong sering terlihat di pelatan sekolah. Misalnya, pada hari senin, menjelang waktu istirahat usai, tiba-tiba di depan ruangan kelas tiga terlihat ramai. Suci (kelas 3 puteri) berseru dengan semangat, "Ayo membersihkan dulu sebelum masuk ustazhah Wanda!" Teman-temannya pun dengan cepat membagi tugas, ada yang menyapu, memperbaiki hiasan dinding, mengepel dan membersihkan toilet tanpa didampingi oleh guru. Qanita (kelas 3 puteri) juga tak kalah semangatnya mengomandoi teman-temannya, "Yang tidak adami kerjanya masukmi ruangan!" sambil merapikan hiasan dinding. Selain Suci dan Qonita, beberapa siswa lain silih berganti masuk ke kamar mandi untuk mencuci alat pel. Muslimah (kelas 3 puteri) membersihkan toilet, sementara Ita (kelas 3 puteri) mengepel lantai, "butuh bantua!" teriak Ita. Spontan temantemannya datang membantu.

\section{Karakter Integritas}

Karakter integritas terihat di depan masjid menjelang salah zuhur, pada saat itu Naila (kelas 2 puteri) menemukan uang pecahan Rp. 2.000 di dekat tas temannya saat akan masuk masjid. Naila tanpa pikir panjang langsung memasukkan kembali uang itu ke dalam tas temannya. Selain Naila, ada Ayu (kelas 6 puteri) yang membawa amplop masuk ke dalam ruangan guru. Saat guru bertanya amplop apa yag dibawa Ayu. Ayu menceritakan bahwa isi amplop itu adalah uang sejumlah Rp. 3.000.000,- yang dititipkan oleh salah satu guru untuk disampaikan kepada kepala sekolah. Naila dan Ayu adalah contoh dari siswa yang memiliki karakter integritas, yakni amanah dan dapat dipercaya.

Implementasi penguatan karakter yang dilakukan oleh sekolah, dalam hal ini guru di Sekolah Dasar Qur'ani Al Ikhlas adalah dengan memberi pujian sembari mengusap kepala murid jika mereka menunjukkan karakter yang baik. Guru juga senangtiasa menggunakan sapaan yang positif baik lisan maupun tertulis, dengan cara memanggil siswa dengan sebutan "anak salih dan shalihah". Selain itu, implementasi penguatan karakter juga dilakukan melalui teguran yang lembut, misalnya kalimat "Anak shalih duduknya bagaimana?" disampaikan oleh guru kepada siswa yang melakukan pelanggaran. Selain itu, dalam menguatkan pendidikan karakter, guru menanamkan kebiasaan/budaya mendoakan siswa di depan kelas dengan suara yang tenang. Guru merupakan pusat teladan di sekolah ini. Guru menjadi rolemodel bagi siswa terutama dalam hal kemandirian dan religuis. Tidak jarang di sela-sela proses pembelajaran, guru yang tidak mengajar sering membersihkan di depan ruang kelas, sehingga siswa yang sedang belajar dapat melihat apa yang dilakukan guru tersebut. Lambat laun, 


\section{Jurnal Riset Pendidikan Dasar, 02 (2), Oktober 2019 (81-88)}

Jumiati \& Lababa

siswa akan meneladani apa yang dicontohkan oleh guru.

Penguatan pendidikan karakter di Sekolah Dasar Qur'ani Al Ikhlash Rappang juga diimplementasikan dengan strategi lain berupa program-program mingguan seperti Gerimis (Gerakan Kamis Bersih), Sejuk (Sedekah Jumat), dan shalat dhuha berjemaah.

Dibandingkan dengan implementasi penguatan pendidikan karakter yang dilakukan di Sekolah Kreatif Si Doel, yang menitikberatkan implementasi penguatan pada karakter kraetif, maka di Sekolah Dasar Qur'ani Al Ikhlash Rappang memfokuskan program pada penguatan karakter religuis, integritas, kemandirian dan integritas. Bila implementasi di sekolah Kreatif Si Doel dilakukan melalui kegiatan rutin setiap hari minggu dengan mengadakan kegiatan keteramilan membuat kerajinan tangan, beda halnya dengan Sekolah Dasar Qur'ani Al Ikhlash Rappang, yang merutinkan program Gerimis (Gerakan Kamis Bersih), Sejuk (Sedekah Jumat), dan shalat dhuha berjamaah.

Kegiatan yang dilakukan sebagai bentuk implementasi penguatan karakter di Sekolah Dasar Qur'ani Al Ikhlash Rappang senada dengan apa yang disimpulkan oleh Suci dan Hidayat (2019) bahwa karakter yang baik harus dilaksanakan dengan cara pembiasaan yang baik pula.

\section{SIMPULAN}

Berdasarkan hasil penelitian dan pembahasan, diperoleh beberapa simpulan sebagai berikut:

1. Sekolah dasar Qurani Al Ikhlash Rappang merupakan sekolah berbasis Islam yang didirikan pada tahun 2014 atas kerjasama antara Yayasan Wahdaislammiyah dengan masyarakat setempat dan orang tua murid.

2. Penguatan pendidikan karakter di Sekolah Dasar Qur'ani Al Ikhlash Rappang diimplementasikan melalui budaya, prinsip, dan sistem sekolah yang tegas dan lugas. implementasi penguatan pendidikan karakter sekolah dasar Qur'ani Al Ikhlash Rappang dilakukan melalui budaya dan sistem sekolah yang meliputi: keteladanan, tarbiyah, pengkondisian, nasihat baik yang repetitif, pola komunikasi, dan konsep 9K (kerapian, kebersihan, ketertiban, kesopanan, keindahan, kerindangan, kedisiplinan, keimanan, dan ketakwaan).

\section{DAFTAR PUSTAKA}

Badan penelitian dan Pengembangan. (2010). Panduan pengembangan pendidikan dan budaya bangsa. Jakarta: Kemendiknas.

Channel, D. (2012, Juni 26). Tujuan pendidikan karakter. Dipetik Agustus 26, 2018, dari Jurnalmasi:

http://jurnalmadi.blogspot.com/2012/06 /tujuan-pendidikankarakter-adalah.html.

Handayani, S. (2017, September 28). Majalah Didik. Dipetik Agustus 23, 2018, dari Majalah Didik Mencerdaskan Bangsa: https://majalahdidik.web.id.

Jalal, F. (2010). Kebijakan Nasional Pendidikan karakter: Tiga Stream Pendekatan. Jakarta: Kementerian Pendidikan Nasional.

Judiani, S. (2010). Implementasi pendidikan karakter di sekolah dasar melalui penguatan pelaksanaan kurikulum. Jurnal Pendidikan dan Kebudayaan Vol 16, Edisi Khusus III , 280-289.

Kementerian Pendidikan Nasional. (2010). Bahan pelatihan penguatan metodologi pembelajaran berdasarkan nilai-nilai budaya untuk membentuk daya saing dan karakter bangsa. Jakarta: Pusat Kurikulum, Badan Penelitian dan Pengambangan.

LB, I., Danim, S., \& Somantri, M. (2018). Kebijakan kepada sekolah dalam implementasi pendidikan karakter di SMP Negeri 1 Bengkulu Utara. Seminar Nasional Administrasi dan Manajemen Pendidikan (hal. 56). Makassar: UNM.

Ma'arif, M. A., \& Hamid, A. (2018). Pendidikan karakter berbasis pendidikan Islam. Jurnal An-Nisa' . 
Mardian, \& Muliyani, S. (2018). Pembentukan pendidikan karakter melalui sastra anak berbantuan media gambar. Jurnal Sastra , 100-107.

Nurhadi. (2018). Pola relasi pendidikan keluarga masyarakat dan sekolah. Jurnal An-Nisa' .

Pambudi, \& Riyan, S. (2017). Implementasi Pendidikan Karakter di Sekolah Kreatif Si Doel. Yogyakarta: Universitas Negeri Yogyakarta.

Putri, \& Palupi, D. (2018). Pendidikan karakter pada anak sekolah dasar di era digital. Jurnal Pendidikan, 38.

Saptiana, N. (2017). Dipetik 8 24, 2018, dari Kompasiana:

https://www.kompasiana.com/novisaptia na

Sari, I. K., Nasution, L., \& Wijaya, C. (2019). Integrasi pendidikan nilai dalam membangun karakter siswa di Sekolah Dasar Jampalan Kecamatan Simpang Empat Kabupaten Asahan Provinsi Sumatera Utara. Jurnal Ristekdik: Jurnal Bimbingan dan Konseling .

Suci, N. A., \& Hidayat, S. (2019). Pendidikan karakter: Penumbuhan kreativitas siswa melalui program ekstrakurikuler teater di sekolah dasar. Jurnal Pedadidaktika , 29 235.

Syaifuddin, A. (2014, Juli 20). Tips pendidikan. Dipetik Agustus 27, 2018, dari Tips Pendidikan:

http://www.tipspendidikan.site/214/7/p engertian-tujuan-dan18-nilai.html.

Widyastono, H. (2010). Bahan pelatihan penyelenggaraan pendidikan karakter di sekolah. Jakarta: Yayasan Pendidikan Masjid Panglima Besar Jendral Sudirman.

Zuchdi, D. (2010). Pengembangan model pendidikan karakter terintegrasi dalam pembelajaran bidang studi di sekolah dasar. Cakrawala Pendidikan, 1-12. 